This document is confidential and is proprietary to the American Chemical Society and its authors. Do not copy or disclose without written permission. If you have received this item in error, notify the sender and delete all copies.

\title{
Enantioselective Synthesis and Activity of all Diastereoisomers of (E)-Phytal, a Pheromone Component of the Moroccan Locust, Dociostaurus maroccanus
}

\begin{tabular}{|r|l|}
\hline Journal: & Journal of Agricultural and Food Chemistry \\
\hline Manuscript ID & jf-2018-06346h.R1 \\
\hline Danuscript Type: & Article \\
\hline Author: & n/a \\
\hline Complete List of Authors: & $\begin{array}{l}\text { Guerrero, Angel; Institute of Advanced Chemistry of Catalonia (CSIC), } \\
\text { Department of Biological Chemistry and Molecular Modelling } \\
\text { Ramos, Victoria Elena; Institute of Advanced Chemistry of Catalonia } \\
\text { (CSIC), Department of Biological Chemistry and Molecular Modelling } \\
\text { López, Sergio; Institute of Advanced Chemistry of Catalonia (CSIC), } \\
\text { Department of Biological Chemistry and Molecular Modelling } \\
\text { Álvarez-Calero, José ; Institute of Advanced Chemistry of Catalonia } \\
\text { (CSIC), Department of Biological Chemistry and Molecular Modelling } \\
\text { Dominguez, Aroa; Institute of Advanced Chemistry of Catalonia (CSIC), } \\
\text { Department of Biological Chemistry and Molecular Modelling } \\
\text { Coca, Ma Milagro; Centro de Investigacion y Tecnologia Agroalimentaria } \\
\text { de Aragon, Plant Health Department } \\
\text { Bosch, Ma Pilar; Institute of Advanced Chemistry of Catalonia (CSIC), } \\
\text { Department of Biological Chemistry and Molecular Modelling } \\
\text { Quero, Carmen; Institute of Advanced Chemistry of Catalonia (CSIC), } \\
\text { Department of Biological Chemistry and Molecular Modelling }\end{array}$ \\
\hline
\end{tabular}

\section{SCHOLARONE Manuscripts}


1 Enantioselective Synthesis and Activity of All Diastereoisomers of (E)-

2 Phytal, a Pheromone Component of the Moroccan Locust, Dociostaurus

maroccanus

Angel Guerrero ${ }^{\dagger, *}{ }^{, *}$ ictoria Elena Ramos ${ }^{\dagger}$, Sergio López ${ }^{\dagger}$, José María Alvarez ${ }^{\dagger}$, Aroa Domínguez $^{\dagger}$, María Milagro Coca-Abia $¥$, María Pilar Bosch ${ }^{\dagger}$, and Carmen Quero ${ }^{\dagger}$

†Department of Biological Chemistry and Molecular Modelling, Institute of Advanced Chemistry of Catalonia (CSIC), 08034 Barcelona, Spain

†Plant Health Department, Centro de Investigación y Tecnología Agroalimentaria de Aragón and Instituto Agroalimentario de Aragón-IA2 (CITA-Zaragoza University), 50059 Zaragoza, Spain 


\section{ABSTRACT}

5 The Moroccan locust, Dociostaurus maroccanus (Thunberg, 1815) (Orthoptera: Acrididae),

6 is a polyphagous pest capable of inflicting large losses in agriculture under favorable

7 environmental and climatic conditions. Currently, control of the pest relies solely on the

8 application of conventional insecticides that have negative effects on the environment and

9 human safety. In the search for a more rational, environmentally-acceptable approach for

10 locust control, we have previously reported that $(Z / E)$-phytal (1) is a male-produced

11 candidate sex pheromone of this acridid. This molecule, with two stereogenic centers at C-7

12 and $\mathrm{C}-11$, has four different diastereomers along with the $Z / E$ stereochemistry of the double

13 bond at $\mathrm{C}-2$. In this paper, we present for the first time the enantioselective synthesis of the

14 four diastereomers of (E)-phytal and their electrophysiological and behavioral activity on

15 males and females. Our results demonstrate that the $(R, R)$-phytal is the most active

16 diastereomer in both assays, significantly attracting females in a double-choice Y

17 olfactometer, and confirming the previous chromatographic assignment as component of the

18 sex pheromone of the Moroccan locust.

19 KEYWORDS: Moroccan locust, Dociostaurus maroccanus, sex pheromone, phytal, ,

$20(2 E, 7 R, 11 R)-3,7,11,15$-tetramethylhexadec-2-enal, enantioselective synthesis, electrophysiology, behavioral activity. 
According to data from the Food and Agricultural Organization of the United Nations (FAO) the world food production will need to rise by $70 \%$ and to double in the developing countries by 2050 . In addition, it is likely that these countries will have to face devastating attacks promoted by locust plagues. ${ }^{1}$ Control of outbreaks and plagues of these pests has relied primarily on the application of conventional insecticides to hopper bands and swarms. ${ }^{2}$ These treatments have been highly controversial for environmental, human safety and economic reasons and therefore, alternative, environmentally-friendly strategies for locusts control are urgently needed. ${ }^{2-4}$ First attempts have been implemented using biopesticides based on the fungus Metarhizium anisopliae var. acridum as an alternative biological control measure, ${ }^{5}$ but chemical control nevertheless remains the most effective defence against locusts so far. ${ }^{4}$ The Moroccan locust, Dociostaurus maroccanus (Thunberg, 1815) (Orthoptera: Acrididae), is a polyphagous pest of crops and pastures, particularly in Southern Europe, North Africa and the Middle East, but devastating outbreaks have also been seen in Afghanistan, Iran, and adjacent countries of the former USSR. ${ }^{6-8}$ The locust is highly voracious and, as such, considered a "major pest of many crops". 9 As for other acridid species, like Schistocerca gregaria (Forskål, 1775) or Locusta migratoria (L., 1758), ${ }^{10}$ if environmental and climatic conditions are favorable, the Moroccan locust can also shift from solitarious to gregarious phase, increasing dramatically in number with formation of hopper bands and large landscape-devouring swarms. ${ }^{11}$ This fact has led to an increasing use of insecticides in infested zones to prevent spreading to non-infested areas. Thus, 651,600 ha were treated in Uzbekistan in 1984, 290,000 ha in Kazakhstan in 1993, 219,700 ha in Turkmenistan in 1996, and ca. 650,000 ha in Spain in the period 2004-2007, ${ }^{11,12}$ among others. However, in spite of its economic incidence, no reports have been found in the literature to tackle management of 
study, ${ }^{13}$ we reported the identification, synthesis and biological activity of $(Z / E)$-phytal, 1

48

(Figure 1) as a male-specific candidate sex pheromone compound of the acridid. Biosynthetically, it has been postulated that phytal proceeds from oxidation of phytol in marine bacteria, ${ }^{14,15}$ and later supported by us to occur in the gut of Moroccan locust males. ${ }^{13}$ Like phytol, the alcohol moiety of the chlorophyll molecule, the phytal molecule $(3,7,11,15$ tetramethylhexadec-2-enal, 1) features four methyl substituents, two of them generating a stereogenic center at C-7 and C-11. Therefore, four different diastereoisomers are possible, in addition to the $Z / E$ stereochemistry of the double bond at C-2. Only the natural $(R, R)$-phytal and the racemic compound have been prepared by oxidation of the corresponding phytols ${ }^{13,16,17}$ or by reduction of the corresponding nitrile. ${ }^{18}$ In this study, we developed an enantioselective synthesis of all diastereoisomers of (E)-phytal, 2-5 (Figure 2) from commercially available chiral synthons, and their electrophysiological and behavioral activity on males and females of the Moroccan locust to establish the most active diastereomer as well as the final assignment of the natural pheromone.

\section{MATERIALS AND METHODS}

General. Chemicals and solvents were purchased from commercial suppliers or purified by standard techniques. Racemic and $(2 E, 7 R, 11 R)$-phytol were commercially available from Sigma-Aldrich (Tres Cantos, Madrid, Spain) and TCI Europe (Zwijndrecht, Belgium), respectively. All reactions employing organometallic compounds were carried out under inert atmosphere. IR spectra were recorded on a Avatar 360 FT-IR spectrometer (Thermo Nicolet, Madison, WI). NMR spectra were recorded at $400 \mathrm{MHz}$ for ${ }^{1} \mathrm{H}$ and $100 \mathrm{MHz}$ for ${ }^{13} \mathrm{C}$ on a Mercury 400 spectrometer (Varian, Palo Alto, CA). Spectra were recorded in $\mathrm{CDCl}_{3}$ at ambient temperature using the $\mathrm{CHCl}_{3}$ present in the solvent $\left(7.25 \mathrm{ppm}\right.$ for ${ }^{1} \mathrm{H}$ NMR and 77.0 ppm for ${ }^{13} \mathrm{C}$ NMR spectra) as internal standard. Mass spectra (MS) were obtained on a Trace MS (ThermoQuest-Finnigan, Manchester, United Kingdom) coupled to a GC2000 gas 
chromatograph (ThermoQuest-Finnigan, Milan, Italy). High resolution mass spectra (HRMS) were run on a Acquity UPLC coupled to an LCT Premier XE mass spectrometer (Waters, Milford, MA) using a $50 \mathrm{~mm}$ x $2.1 \mathrm{~mm}$ i.d., $1.7 \mu \mathrm{m}$, BEH C18 column (Waters, Milford, MA) eluting with $\mathrm{CH}_{3} \mathrm{CN} / \mathrm{H}_{2} \mathrm{O}(80: 20$, v/v). Elemental analyses were determined on a Flash 2000 Organic Elemental Analyzer (Thermo Scientific, Cambridge, United Kingdom). Optical rotations were measured on a model 341 polarimeter (Perkin-Elmer, Waltham, MA) at 589 nm.

Synthesis of Diastereomers of (E)-phytal, 2-5 (Figures 3 and 4).

The general approach is represented by the synthesis of $(2 E, 7 S, 11 R)$-phytal, 2 , from the intermediate (2S,6R)-2,6,10-trimethylundecyl alcohol, 6 (Figure 3), as follows: $(2 S, 6 R)-2,6,10-$ Trimethylundecyl methanesulfonate $[(2 S, 6 R)-16]$. To a solution of chiral alcohol $(2 S, 6 R)-6(1.20 \mathrm{~g}, 5.6 \mathrm{mmol})$ in dichloromethane $(11 \mathrm{~mL})$ was added triethylamine $(2.50 \mathrm{~mL}, 18 \mathrm{mmol})$ and methanesulfonyl chloride $(0.78 \mathrm{~mL}, 10.1 \mathrm{mmol})$ at $0{ }^{\circ} \mathrm{C}$. The reaction was stirred at $0{ }^{\circ} \mathrm{C}$ for $1 \mathrm{~h}$, and at room temperature for $3 \mathrm{~h}$. The mixture was quenched with a saturated $\mathrm{NH}_{4} \mathrm{Cl}$ solution $(10 \mathrm{~mL})$ and extracted with ether $(3 \mathrm{x} 40 \mathrm{~mL})$. The combined extracts were washed with brine $(20 \mathrm{~mL})$, dried with anhydrous $\mathrm{Na}_{2} \mathrm{SO}_{4}$, and evaporated under reduced pressure. The residue was chromatographed (silica, hexane/diethyl ether 85:15) to give mesylate $(2 S, 6 R)-16(1.40 \mathrm{~g}, 86 \%)$ as a pale yellow oil. ${ }^{1} \mathrm{H}$ NMR $\delta 4.07$ (dd, $J=9.4,5.7 \mathrm{~Hz}, 1 \mathrm{H}), 3.98(\mathrm{dd}, J=9.4,6.7 \mathrm{~Hz}, 1 \mathrm{H}), 2.98(\mathrm{~s}, 3 \mathrm{H}), 1.86(\mathrm{~m}, 1 \mathrm{H}), 1.50(\mathrm{~m}$, $1 \mathrm{H}), 1.43-1.01(\mathrm{~m}, 13 \mathrm{H}), 0.97(\mathrm{~d}, J=6.7 \mathrm{~Hz}, 3 \mathrm{H}), 0.89-0.80 \mathrm{ppm}(\mathrm{m}, 9 \mathrm{H}) .{ }^{13} \mathrm{C}$ NMR $\delta$ $76.7\left(\mathrm{CH}_{2}\right), 39.3\left(\mathrm{CH}_{2}\right), 37.2\left(\mathrm{CH}_{3}\right), 37.1\left(\mathrm{CH}_{2}\right), 37.0\left(\mathrm{CH}_{2}\right), 33.0(\mathrm{CH}), 32.9\left(\mathrm{CH}_{2}\right), 32.6$ (CH), $27.9(\mathrm{CH}), 24.7\left(\mathrm{CH}_{2}\right), 24.0\left(\mathrm{CH}_{2}\right), 22.6\left(\mathrm{CH}_{3}\right), 22.5\left(\mathrm{CH}_{3}\right), 19.5\left(\mathrm{CH}_{3}\right), 16.4 \mathrm{ppm}$ $\left(\mathrm{CH}_{3}\right)$. IR (film): 2939, 2924, 2871, 1454, 1352, 1322, 1184, 1059, 974, $809 \mathrm{~cm}^{-1}$. MS (EI): m/z (\%): 291 (1) [M-1] $]^{+}, 196$ (25), 168 (11), 154 (9), 140 (24), 126 (81), 111 (91), 97 (77), 83 (83), 69 (100), 57 (95), 43 (94). 
(3S, 7R)-3, 7,11-Trimethyldodecanenitrile [(3S,7R)-17]. To a solution of mesylate $(2 S, 6 R)-\mathbf{1 6}$ (1.40 g, $4.78 \mathrm{mmol})$ in THF/DMSO $(1: 1, \mathrm{v} / \mathrm{v})(14 \mathrm{~mL})$ was added sodium cyanide $(516 \mathrm{mg}$, $10.50 \mathrm{mmol}$ ) and the mixture was refluxed for $3 \mathrm{~h}$. The reaction mixture was cooled to room temperature, quenched with water $(10 \mathrm{~mL})$ and stirred for $10 \mathrm{~min}$. The organic material was extracted with ethyl acetate $(3 \times 35 \mathrm{~mL})$. The combined extracts were washed with brine (20 $\mathrm{mL})$ and water $(15 \mathrm{~mL})$, dried with anhydrous $\mathrm{Na}_{2} \mathrm{SO}_{4}$, and evaporated under reduced pressure. The residue was chromatographed (silica, hexane/diethyl ether 9:1) to give nitrile $(3 S, 7 R)-17(930 \mathrm{mg}, 87 \%)$ as a colourless oil. $[\alpha]_{\mathrm{D}}{ }^{25}=+3.06$ (c 1.11, hexane). ${ }^{1} \mathrm{H}$ NMR $\delta$ $2.31(\mathrm{dd}, J=16.7,5.8 \mathrm{~Hz}, 1 \mathrm{H}), 2.22(\mathrm{dd}, J=16.7,6.8 \mathrm{~Hz}, 1 \mathrm{H}), 1.83(\mathrm{~m}, 1 \mathrm{H}), 1.50(\mathrm{~m}, 1 \mathrm{H})$, $1.43-1.00(\mathrm{~m}, 13 \mathrm{H}), 1.05(\mathrm{~d}, J=6.7 \mathrm{~Hz}, 3 \mathrm{H}), 0.84 \mathrm{ppm}(\mathrm{t}, J=6.9 \mathrm{~Hz}, 9 \mathrm{H}) .{ }^{13} \mathrm{C} \mathrm{NMR} \delta$ $118.9(\mathrm{C}), 39.2\left(\mathrm{CH}_{2}\right), 37.2\left(\mathrm{CH}_{2}\right), 36.8\left(\mathrm{CH}_{2}\right), 36.1\left(\mathrm{CH}_{2}\right), 32.6(\mathrm{CH}), 30.4(\mathrm{CH}), 27.9(\mathrm{CH})$, $24.7\left(\mathrm{CH}_{2}\right), 24.5\left(\mathrm{CH}_{2}\right), 24.2\left(\mathrm{CH}_{2}\right), 22.6\left(\mathrm{CH}_{3}\right), 22.5\left(\mathrm{CH}_{3}\right), 19.5\left(\mathrm{CH}_{3}\right), 19.4 \mathrm{ppm}\left(\mathrm{CH}_{3}\right) . \mathrm{IR}$ (film): 2954, 2925, 2868, 2248, 1461, $1383 \mathrm{~cm}^{-1}$. MS (EI): $\mathrm{m} / z$ (\%): 224 (2) [M+1] $]^{+}, 223$ (1) $[\mathrm{M}]^{+\bullet}, 222(7)[\mathrm{M}-1]^{+}, 208(69), 194(20), 180(70), 166$ (60), 152 (82), 138 (100), 124 (63), 111 (81), 97 (79), 82 (68), 71 (92), 57 (98), 43 (92). HRMS calc for $\mathrm{C}_{15} \mathrm{H}_{28} \mathrm{~N}: 222.2222$ [M$1]^{+}$, found 222.2223 .

(3S,7R)-3,7,11-Trimethyldodecanal [(3S,7R)-18]. A $1 \mathrm{M}$ solution of diisobutylaluminium hydride (DIBAH) in hexane $(5.30 \mathrm{~mL}, 5.30 \mathrm{mmol})$ and nitrile $(3 S, 7 R)-17(928 \mathrm{mg}, 4.09$ mmol) was stirred in hexane $(68 \mathrm{~mL})$ at room temperature under Ar for $2.5 \mathrm{~h}$. Ethanol (55 $\mathrm{mL})$ and water $(35 \mathrm{~mL})$ were added dropwise to the mixture and stirred for $1 \mathrm{~h}$. The mixture was extracted with diethyl ether $(3 \times 40 \mathrm{~mL})$. The combined extracts were washed with $3 \mathrm{M}$ $\mathrm{HCl}(25 \mathrm{~mL})$, water $(25 \mathrm{~mL})$, saturated sodium hydrogen carbonate solution $(25 \mathrm{~mL})$ and brine $(25 \mathrm{~mL})$. After drying with anhydrous $\mathrm{Na}_{2} \mathrm{SO}_{4}$, the solvent was evaporated under reduced pressure to furnish aldehyde $(3 S, 7 R)-18(916 \mathrm{mg}, 97 \%)$ as a colourless oil, pure enough for the next step without need of further purification. $[\alpha]_{\mathrm{D}}^{25}=-1.22$ (c 1.14, hexane). 
${ }^{1} \mathrm{H}$ NMR $\delta 9.74(\mathrm{t}, J=2.3 \mathrm{~Hz}, 1 \mathrm{H}), 2.38(\mathrm{ddd}, J=16.0,5.7,2.0 \mathrm{~Hz}, 1 \mathrm{H}), 2.21(\mathrm{ddd}, J=16.0$, 7.8, 2.6 Hz, $1 \mathrm{H}), 2.03(\mathrm{~m}, 1 \mathrm{H}), 1.59-0.99$ (m, $14 \mathrm{H}), 0.94$ (d, J=6.6 Hz, $3 \mathrm{H}), 0.84$ ppm (dd, $J=8.7,6.6 \mathrm{~Hz}, 9 \mathrm{H}) .{ }^{13} \mathrm{C} \mathrm{NMR} \delta 203.1(\mathrm{CH}), 51.1\left(\mathrm{CH}_{2}\right), 39.3\left(\mathrm{CH}_{2}\right), 37.3\left(\mathrm{CH}_{2}\right), 37.2$ $\left(\mathrm{CH}_{2}\right), 37.0\left(\mathrm{CH}_{2}\right), 32.6(\mathrm{CH}), 28.1(\mathrm{CH}), 27.9(\mathrm{CH}), 24.7\left(\mathrm{CH}_{2}\right), 24.3\left(\mathrm{CH}_{2}\right), 22.6\left(\mathrm{CH}_{3}\right), 22.5$ $\left(\mathrm{CH}_{3}\right), 19.9\left(\mathrm{CH}_{3}\right), 19.5$ ppm $\left(\mathrm{CH}_{3}\right)$. IR (film): 2952, 2924, 2868, 1728, 1461, 1377, 1365 , 1144, $976 \mathrm{~cm}^{-1}$. MS (EI): $m / z$ (\%): 226 (1) [M] $]^{+}, 182$ (67), 154 (9), 137 (18), 126 (74), 123 (85), 111 (69), 97 (89), 81 (87), 71 (100), 57 (95), 43 (94). HRMS calc for $\mathrm{C}_{15} \mathrm{H}_{29} \mathrm{O}$ : $225.2218[\mathrm{M}-1]^{+}$, found 225.2224 .

2,4-Dimethylpent-3-yl 3-methylbut-2-enoate (19). This compound was obtained from dimethylacrylic acid (4.00 g, $40 \mathrm{mmol})$, 2,4-dimethylpentan-3-ol (14 mL, $100 \mathrm{mmol})$ in the presence of 4,4'-dimethylaminopyridine (440 mg, $3.6 \mathrm{mmol}$ ) in dichloromethane and N,N'dicyclohexylcarbodiimide (1.0 M in dichloromethane, $48 \mathrm{~mL}, 48 \mathrm{mmol}$ ) to give ester 19 in $51 \%$ isolated yield, as previously described. ${ }^{19}$

((1-(2,4-Dimethylpent-3-yloxy)-3-methylbuta-1,3-dien-1-yl)oxy)trimethylsilane (20). This compound was prepared by reaction of ester 19 (4.08 g, $20.6 \mathrm{mmol})$ with lithium diisopropylamide (LDA) $(22.7 \mathrm{mmol})$ in hexane followed by the addition of chlorotrimethylsilane (TMSCl) $(4.70 \mathrm{~mL}, 37.08 \mathrm{mmol})$ to provide enol ether $\mathbf{2 0}$ (4.96 g, 89\%; 95\% pure by ${ }^{1} \mathrm{H}$ NMR), as previously described. ${ }^{19}$ The compound was used in the next step without further purification.

\section{2,4-Dimethylpent-3-yl $\quad(2 E, 5 R S, 7 S, 11 R)$-5-hydroxy-3,7,11,15-tetramethylhexadec-2-enoate} [(2E,5RS,7S, 11R)-21]. A solution of silyl enol ether $20(3.60 \mathrm{~g}, 12.63 \mathrm{mmol})$ in dichloromethane $(10 \mathrm{~mL})$ was added at $-78^{\circ} \mathrm{C}$ to a mixture of aldehyde $(3 S, 7 R)-18(916 \mathrm{mg}$, $4.04 \mathrm{mmol})$ in dichloromethane $(25 \mathrm{~mL})$ and $1.0 \mathrm{M}$ solution of titanium tetrachloride in dichloromethane $(12.5 \mathrm{~mL}, 12.5 \mathrm{mmol})$ over $20 \mathrm{~min}$. The mixture was stirred at $-78^{\circ} \mathrm{C}$ for 1 $\mathrm{h}$, left to warm to room temperature, and quenched with saturated sodium hydrogen carbonate 
solution $(80 \mathrm{~mL})$. After extraction with diethyl ether $(3 \times 40 \mathrm{~mL})$, the extracts were combined, washed with brine $(20 \mathrm{~mL})$, dried with anhydrous $\mathrm{Na}_{2} \mathrm{SO}_{4}$ and concentrated under reduced pressure. The residue was purified by column chromatography (silica gel, hexane/diethyl ether $98: 2$ to $95: 5)$ to give alcohol $(2 E, 5 R S, 7 S, 11 R)-21(246 \mathrm{mg}, 14 \%)$ as a colourless oil (none of the $Z$ isomer was detected). Stereomeric mixture: ${ }^{1} \mathrm{H}$ NMR $\delta 5.76$ (s, 1 H), $4.61(\mathrm{t}, J=6.2 \mathrm{~Hz}, 1 \mathrm{H}), 3.95-3.78(\mathrm{~m}, 1 \mathrm{H}), 2.25(\mathrm{~m}, 2 \mathrm{H}), 2.19(\mathrm{~s}, 3 \mathrm{H}), 1.89(\mathrm{~m}, 2 \mathrm{H})$, 1.75-1.01 (m, $18 \mathrm{H}), 0.95-0.81 \mathrm{ppm}(\mathrm{m}, 24 \mathrm{H}) .{ }^{13} \mathrm{C}$ NMR $\delta 166.5(\mathrm{C}), 155.7(\mathrm{C}), 118.4$ (CH), $81.7(\mathrm{CH}), 67.3(\mathrm{CH}), 67.0(\mathrm{CH}), 49.8\left(\mathrm{CH}_{2}\right), 44.8\left(\mathrm{CH}_{2}\right), 39.3\left(\mathrm{CH}_{2}\right), 38.1\left(\mathrm{CH}_{3}\right), 37.3$ $\left(\mathrm{CH}_{2}\right), 37.2\left(\mathrm{CH}_{2}\right), 37.1\left(\mathrm{CH}_{2}\right), 32.7(\mathrm{CH}), 29.4(\mathrm{CH}), 29.2(\mathrm{CH}), 27.9(\mathrm{CH}), 24.7\left(\mathrm{CH}_{2}\right), 24.3$ $\left(\mathrm{CH}_{2}\right), 22.7\left(\mathrm{CH}_{3}\right), 22.6\left(\mathrm{CH}_{3}\right), 20.0\left(\mathrm{CH}_{3}\right), 19.6\left(\mathrm{CH}_{3}\right), 19.5\left(\mathrm{CH}_{3}\right), 19.1\left(\mathrm{CH}_{3}\right), 17.3\left(2 \mathrm{CH}_{3}\right)$, $17.2 \mathrm{ppm}\left(2 \mathrm{CH}_{3}\right)$. IR (film): 3384 (b), 2956, 2926, 2867, 1715, 1644, 1462, 1220, $1129 \mathrm{~cm}^{-1}$. MS (EI): $m / z(\%): 423$ (1) [M-1] $]^{+}, 309$ (49), 198 (21), 123 (15), 111 (41), 100 (100), 83 (86), 71 (53), 57 (83), 43 (65). HRMS calc for $\mathrm{C}_{27} \mathrm{H}_{53} \mathrm{O}_{3}: 425.3995[\mathrm{M}+1]^{+}$, found 425.3976.

2,4-Dimethylpent-3-yl $\quad(2 E, 5 R S, 7 S, 11 R)-3,7,11,15$-tetramethyl-5-(methylsulfonyloxy)hexadec-2-enoate [(2E,5RS, 7S, 11R)-22]. To a solution of alcohol (2E,5RS,7S,11R)-21 (245 mg, $0.58 \mathrm{mmol})$ in dichloromethane $(2.5 \mathrm{~mL})$ was added anhydrous triethylamine $(0.4 \mathrm{~mL}, 2.9$ mmol) and methanesulfonyl chloride $(0.14 \mathrm{~mL}, 1.73 \mathrm{mmol})$ at $0{ }^{\circ} \mathrm{C}$. The reaction was stirred at $0{ }^{\circ} \mathrm{C}$ for $1 \mathrm{~h}$ and at room temperature for $2 \mathrm{~h}$. The mixture was quenched with a saturated $\mathrm{NH}_{4} \mathrm{Cl}$ solution $(10 \mathrm{~mL})$ and extracted with diethyl ether $(3 \times 15 \mathrm{~mL})$. The combined extracts were washed with brine $(10 \mathrm{~mL})$ and water $(10 \mathrm{~mL})$, dried with anhydrous $\mathrm{Na}_{2} \mathrm{SO}_{4}$, and evaporated under reduced pressure. The residue was chromatographed (silica, hexane/ethyl acetate, $98: 2$ to $96: 4)$ to give mesylate $(2 E, 5 R S, 7 S, 11 R)-22(181 \mathrm{mg}, 63 \%)$ as a pale yellow oil. This compound was used immediately for the next step. Stereomeric mixture: ${ }^{1} \mathrm{H}$ NMR $\delta$ $5.76(\mathrm{~s}, 1 \mathrm{H}), 5.03-4.89(\mathrm{~m}, 1 \mathrm{H}), 4.61(\mathrm{t}, J=6.2 \mathrm{~Hz}, 1 \mathrm{H}), 2.95$ and $2.93(2 \mathrm{~s}, 3 \mathrm{H}), 2.66-2.37$ (m, 2 H), $2.20(\mathrm{~s}, 3 \mathrm{H}), 1.89(\mathrm{~m}, 2 \mathrm{H}), 1.81-0.99(\mathrm{~m}, 14 \mathrm{H}), 0.93$ (d, J=6.4 Hz, $3 \mathrm{H}), 0.90-$ 
0.79 ppm (m, $24 \mathrm{H}) .{ }^{13} \mathrm{C}$ NMR $\delta 166.2(\mathrm{C}), 153.0(\mathrm{C}), 119.1(\mathrm{CH}), 81.9(\mathrm{CH}), 79.6(\mathrm{CH})$, $79.2(\mathrm{CH}), 46.8\left(\mathrm{CH}_{2}\right), 46.1\left(\mathrm{CH}_{2}\right), 42.5\left(\mathrm{CH}_{2}\right), 42.2\left(\mathrm{CH}_{2}\right), 39.3\left(\mathrm{CH}_{2}\right), 38.7\left(\mathrm{CH}_{3}\right), 37.5$ $\left(\mathrm{CH}_{2}\right), 37.2\left(\mathrm{CH}_{2}\right), 36.8\left(\mathrm{CH}_{2}\right), 32.7(\mathrm{CH}), 29.3(\mathrm{CH}), 29.0(\mathrm{CH}), 27.9(\mathrm{CH}), 24.7\left(\mathrm{CH}_{2}\right), 24.1$ $\left(\mathrm{CH}_{2}\right), 24.0\left(\mathrm{CH}_{2}\right) 22.6\left(\mathrm{CH}_{3}\right), 22.5\left(\mathrm{CH}_{3}\right), 19.6\left(\mathrm{CH}_{3}\right), 19.5\left(2 \mathrm{CH}_{3}\right), 19.1\left(\mathrm{CH}_{3}\right), 19.0\left(\mathrm{CH}_{3}\right)$, $18.9\left(\mathrm{CH}_{3}\right), 17.2 \mathrm{ppm}\left(4 \mathrm{CH}_{3}\right)$. IR (film): 2952, 2925, 2867, 1709, 1629, 1366, 1314, 1171, $1054,967,796,750 \mathrm{~cm}^{-1}$. [(2E,5RS, 7S, 11R)-23]. A 1.2M solution of diisobutylaluminium hydride in toluene $(1.5 \mathrm{~mL}$, $1.80 \mathrm{mmol})$ was added to a cold $\left(-78^{\circ} \mathrm{C}\right)$ solution of mesylate $(2 E, 5 R S, 7 S, 11 R)-22(180 \mathrm{mg}$, $0.36 \mathrm{mmol})$ in anhydrous THF $(0.7 \mathrm{~mL})$. After $2 \mathrm{~h}$ of stirring, the reaction mixture was warmed to $-20{ }^{\circ} \mathrm{C}$ and stirred for $2 \mathrm{~h}$ more. Then, saturated $\mathrm{NH}_{4} \mathrm{Cl}$ solution $(1 \mathrm{~mL})$ was added and the reaction mixture allowed to reach room temperature. The mixture was extracted with ethyl acetate $(3 \times 10 \mathrm{~mL})$ and the combined extracts were washed with brine $(2 \times 4 \mathrm{~mL})$, dried with anhydrous $\mathrm{Na}_{2} \mathrm{SO}_{4}$ and concentrated in vacuo. The crude was passed through a pad of silica gel eluting with ether to give alcohol $(2 E, 5 R S, 7 S, 11 R)-23(138 \mathrm{mg}, 96 \%)$ as a colourless oil. This compound was used immediately for the next step without purification. Stereomeric mixture: ${ }^{1} \mathrm{H}$ NMR $\delta 5.51(\mathrm{t}, J=6.5 \mathrm{~Hz}, 1 \mathrm{H}), 4.92(\mathrm{~m}, 1 \mathrm{H}), 4.13(\mathrm{~m}, 2 \mathrm{H}), 2.97$ and $2.96(2 \mathrm{~s}, 3 \mathrm{H}), 2.50-2.21(\mathrm{~m}, 2 \mathrm{H}), 1.72(\mathrm{~s}, 3 \mathrm{H}), 1.64-0.97(\mathrm{~m}, 17 \mathrm{H}), 0.91(\mathrm{dd}, J=6.3$, $3.7 \mathrm{~Hz}, 3 \mathrm{H}), 0.87-0.75$ ppm (m, $9 \mathrm{H}) .{ }^{13} \mathrm{C}$ NMR $\delta 134.4(\mathrm{C}), 128.0(\mathrm{CH}), 80.3(\mathrm{CH}), 80.1$ $27.9(\mathrm{CH}), 24.7\left(\mathrm{CH}_{2}\right), 24.2\left(\mathrm{CH}_{2}\right), 24.0\left(\mathrm{CH}_{2}\right), 22.6\left(\mathrm{CH}_{3}\right), 22.5\left(\mathrm{CH}_{3}\right), 19.7\left(\mathrm{CH}_{3}\right), 19.6$ $902 \mathrm{~cm}^{-1}$. 
(2E,7S,11R)-3,7,11,15-Tetramethylhexadec-2-en-1-ol, $\quad(2 E, 7 S, 11 R)$-phytol, $\quad 24 . \quad$ A $1.0 \mathrm{M}$ solution of lithium aluminium hydride in ether $(0.55 \mathrm{~mL}, 0.55 \mathrm{mmol})$ was added dropwise to a solution of compound $(2 E, 5 R S, 7 S, 11 R)-23(138 \mathrm{mg}, 0.353 \mathrm{mmol})$ in anhydrous ether $(2.0$ $\mathrm{mL})$ at room temperature, and the mixture was stirred for $4 \mathrm{~h}$. Then, water $(0.3 \mathrm{~mL})$ was added followed by $1 \mathrm{M} \mathrm{HCl}(0.3 \mathrm{~mL})$. The mixture was extracted with ethyl acetate $(3 \times 10$ $\mathrm{mL})$, the combined extracts were washed with brine $(2 \times 5 \mathrm{~mL})$, dried with anhydrous $\mathrm{Na}_{2} \mathrm{SO}_{4}$ and concentrated in vacuo. The residue was chromatographed (silica gel, hexane/ethyl acetate, $95: 5)$ to give $80 \mathrm{mg}$ of a mixture of $(2 E, 7 S, 11 R)$-phytol, $\mathbf{2 4}, \alpha, \beta, \gamma, \delta$ diunsaturated alcohol $(2 E, 4 E, 7 S, 11 R)-\mathbf{2 4 a}$, and $(7 S, 11 R)-2,3$-dihydrophytol in 78:5:17 ratio as a clear oil. 24: ${ }^{1} \mathrm{H}$ NMR $\delta 5.39(\mathrm{tq}, J=6.9,1.3 \mathrm{~Hz}, 1 \mathrm{H}), 4.25(\mathrm{~d}, J=7.0 \mathrm{~Hz}, 2 \mathrm{H}), 1.97$ (t, $\mathrm{J}=7.9 \mathrm{~Hz}, 2 \mathrm{H}), 1.64(\mathrm{~s}, 3 \mathrm{H}), 1.57-0.95(\mathrm{~m}, 19 \mathrm{H}), 0.90-0.77 \mathrm{ppm}(\mathrm{m}, 12 \mathrm{H}) .{ }^{13} \mathrm{C} \mathrm{NMR} \delta$ $140.2(\mathrm{C}), 123.0(\mathrm{CH}), 59.4\left(\mathrm{CH}_{2}\right), 39.8\left(\mathrm{CH}_{2}\right), 39.3\left(\mathrm{CH}_{2}\right), 37.3\left(\mathrm{CH}_{2}\right), 37.2\left(\mathrm{CH}_{2}\right), 37.2$ $\left(\mathrm{CH}_{2}\right), 36.7\left(\mathrm{CH}_{2}\right), 32.7(\mathrm{CH}), 32.6(\mathrm{CH}), 27.9(\mathrm{CH}), 25.1\left(\mathrm{CH}_{2}\right), 24.8\left(\mathrm{CH}_{2}\right), 24.4\left(\mathrm{CH}_{2}\right)$, $22.6\left(\mathrm{CH}_{3}\right), 22.5\left(\mathrm{CH}_{3}\right), 19.6\left(2 \mathrm{CH}_{3}\right), 16.1 \mathrm{ppm}\left(\mathrm{CH}_{3}\right)$. IR (film): 3324 (b), 2952, 2924, 2866, 1669, 1461, 1377, $1000 \mathrm{~cm}^{-1}$. MS (EI): $m / z$ (\%): 296 (1) [M] $]^{+}, 196$ (4), 179 (3), 151 (4), 137 (11), 123 (76), $111(39), 95$ (68), $81(77), 71(100), 57(75), 43(74)$. $[\alpha]_{\mathrm{D}}^{25}=-0.91$ (c 0.99 , $\mathrm{CHCl}_{3}$ ). 24a (characteristic data): ${ }^{1} \mathrm{H}$ NMR $\delta 6.05(\mathrm{~d}, \mathrm{~J}=15.4 \mathrm{~Hz}, 1 \mathrm{H}), 5.68(\mathrm{dt}, \mathrm{J}=15.0,7.3$ $\mathrm{Hz}, 1 \mathrm{H}), 5.55$ (bt, J=6.9 Hz, 1H), 4.26 (d, J=7.3 Hz, 2H). ${ }^{13} \mathrm{C}$ NMR $\delta 134.9(\mathrm{C}), 129.3$ (CH), $127.5(\mathrm{CH}), 125.3(\mathrm{CH}), 61.35\left(\mathrm{CH}_{2}\right) .(7 \mathrm{~S}, 11 R)-2,3-$ Dihydrophytol (characteristic data): ${ }^{1} \mathrm{H}$ NMR $\delta 3.72(\mathrm{~m}, 2 \mathrm{H}) .{ }^{13} \mathrm{C}$ NMR $\delta 61.31\left(\mathrm{CH}_{2}\right)$.

(2E,7S,11R)-3,7,11,15-Tetramethylhexadec-2-enal, (2E,7S,11R)-phytal, 2. Activated $\mathrm{MnO}_{2}$ (470 mg, $5.40 \mathrm{mmol})$ was added at room temperature to a solution of $(2 E, 7 S, 11 R)$-phytol, 24 (80 $\mathrm{mg}, 0.27 \mathrm{mmol})$ in dichloromethane $(1.4 \mathrm{~mL})$ and the reaction mixture was refluxed for $24 \mathrm{~h}$. The solid was then filtered through a Celite pad and washed with dichloromethane. The combined organic layers were concentrated in vacuo, and the residue was purified by column 
chromatography (silica, hexane/diethyl ether, 95:5) to obtain $(2 E, 7 S, 11 R)$-phytal, 2 as a clear

222

223

224

225

226

227

228

229

230

231

232

233

234

235

236

237

238

239

240

241

242

243

244

245

oil in three batches: first batch, $22 \mathrm{mg}, 94 \%$ pure by ${ }^{1} \mathrm{H}$ NMR, $E / Z$ ratio $96: 4$, containing $6 \%$

of $\alpha, \beta, \gamma, \delta$-diunsaturated aldehyde $(2 E, 4 E, 7 S, 11 R)-\mathbf{2 a}$; second batch, $12 \mathrm{mg}, 86 \%$ pure by ${ }^{1} \mathrm{H}$ NMR; E/Z ratio $96: 4$, containing $14 \%$ of $\mathbf{2 a}$; third batch, $20 \mathrm{mg}, 76 \%$ pure by ${ }^{1} \mathrm{H} \mathrm{NMR}$, containing $12 \%$ of $\mathbf{2 a}$. The calculated yield of pure $\mathbf{2}$ was $58 \% . E$ isomer $(2 E, 7 S, 11 R)-\mathbf{2}:{ }^{1} \mathrm{H}$ NMR $\delta 9.99(\mathrm{~d}, J=8.1 \mathrm{~Hz}, 1 \mathrm{H}), 5.87(\mathrm{dq}, J=8.1,1.1 \mathrm{~Hz}, 1 \mathrm{H}), 2.21-2.13(\mathrm{~m}, 2 \mathrm{H}), 2.15(\mathrm{~d}$, $\mathrm{J}=1.2 \mathrm{~Hz}, 3 \mathrm{H}), 1.60-0.96(\mathrm{br}, 19 \mathrm{H}), 0.88-0.77 \mathrm{ppm}(\mathrm{m}, 12 \mathrm{H}) .{ }^{13} \mathrm{C}$ NMR $\delta 191.4(\mathrm{CHO})$, $164.4(\mathrm{C}), 127.2(\mathrm{CH}), 40.9\left(\mathrm{CH}_{2}\right), 39.3\left(\mathrm{CH}_{2}\right), 37.3\left(2 \mathrm{CH}_{2}\right), 37.2\left(\mathrm{CH}_{2}\right), 36.5\left(\mathrm{CH}_{2}\right), 32.7$ $(\mathrm{CH}), 32.6(\mathrm{CH}), 27.9(\mathrm{CH}), 24.7\left(\mathrm{CH}_{2}\right), 24.6\left(\mathrm{CH}_{2}\right), 24.3\left(\mathrm{CH}_{2}\right), 22.6\left(\mathrm{CH}_{3}\right), 22.5\left(\mathrm{CH}_{3}\right)$, $19.6\left(\mathrm{CH}_{3}\right), 19.5\left(\mathrm{CH}_{3}\right), 17.4$ ppm $\left(\mathrm{CH}_{3}\right)$. IR (film): 2952, 2924, 2867, 1675, 1632, 1461 , 1379, 1193, 1116, 864, $735 \mathrm{~cm}^{-1}$. MS (EI): $m / z(\%): 294$ (2) [M] $]^{+}, 279$ (3), 276 (3), 263 (7), 194 (8), 191 (10), 179 (10), 163 (25), 150 (26), 149 (64), 140 (61), 139 (56), 121 (66), 111 (76), $97(84), 84(100), 71(75), 69(77), 57(79), 55(79), 43(78) \cdot[\alpha]_{\mathrm{D}}^{25}=+0.55(\mathrm{c}=0.90$, ethanol). HRMS calc for $\mathrm{C}_{20} \mathrm{H}_{39} \mathrm{O}: 295.3001[\mathrm{M}+1]^{+}$, found 295.2988. $Z$ isomer $(2 Z, 7 S, 11 R)-$ 2 (characteristic data): ${ }^{1} \mathrm{H}$ NMR $\delta 9.95$ (d, $\left.J=8.3 \mathrm{~Hz}, 1 \mathrm{H}, \mathrm{CHO}\right) .{ }^{13} \mathrm{C}$ NMR $\delta 190.7$ (CHO), 164.8 (C), $128.4(\mathrm{CH}) . \mathrm{MS}(\mathrm{EI}): m / z(\%): 294$ (1) [M] $]^{+}, 279$ (1), 263 (3), 191 (3), 179 (4), 163 (9), 150 (10), 149 (26), 140 (23), 139 (23), 121 (29), 111 (47), 97 (84), 95 (42), 84 (100), 83 (56), 69 (58), 57 (67), 55 (63), 43 (71). $\alpha, \beta, \gamma, \delta$-Unsaturated aldehyde $(2 E, 4 E, 7 S, 11 R)-\mathbf{2 a}$ (characteristic data): ${ }^{1} \mathrm{H}$ NMR $\delta 10.10$ (d, $\left.J=8.1 \mathrm{~Hz}, 1 \mathrm{H}, \mathrm{CHO}\right) .{ }^{13} \mathrm{C}$ NMR $\delta 191.4(\mathrm{CHO})$, $154.8(\mathrm{C}), 138.6(\mathrm{CH}) .134 .4(\mathrm{CH}), 128.3(\mathrm{CH}) . \mathrm{MS}(\mathrm{EI}) \mathrm{m} / z(\%): 292(4)\left(\mathrm{M}^{+}\right), 277$ (1), 208 (2), 179 (2), 137 (6), 110 (16), 109 (40), 96 (52), 95 (100), 81 (37), 71 (38), 57 (51), 55(45), $43(51)$.

Synthesis of $(2 E, 7 R, 11 S)$-phytal, 3, and $(2 E, 7 S, 11 S)$-phytal, 4 (Figure 2).

These compounds were obtained by a route similar to 2 from the corresponding alcohols.

Synthesis of $(2 E, 7 R, 11 R)-p h y t a l, 5$ (Figure 2). 
246 This compound was obtained from commercially available $(2 E, 7 R, 11 \mathrm{R})$-phytol in $85 \%$ yield,

247 as previously reported. ${ }^{13}$

248 Insects. Fourth- and fifth-instar nymphs (N4 and N5) and adults of D. maroccanus were

249 collected from the field around Alhama de Aragón (Zaragoza) (840 m altitude, Latitude (41

250 20' 58.54', ( $\left.{ }^{\circ} \mathrm{N}\right) /$ Longitude $\left(1^{\circ} 55^{\prime} 39.733^{\prime}\left({ }^{\circ} \mathrm{W}\right)\right)$, Alcudia Valley (Ciudad Real) (685 m

251 altitude, Latitude $\left(38^{\circ} 34^{\prime} 49.08^{\prime \prime}\left({ }^{\circ} \mathrm{N}\right) /\right.$ Longitude $\left(4^{\circ} 20^{\prime} 0.60^{\prime \prime}\left({ }^{\circ} \mathrm{W}\right)\right)$, and Tierra de

252

Ledesma (Salamanca) (833 m altitude, Latitude (41 ${ }^{\circ} 3{ }^{\prime} 7.00^{\prime \prime}\left({ }^{\circ} \mathrm{N}\right) /$ Longitude $\left(6^{\circ} 13^{\prime} 33.12^{\prime}\right.$,

253

$\left.\left({ }^{\circ} \mathrm{W}\right)\right)$ during the period May-July 2013-2018. After collection, insects were placed in

50x50x50 cm metallic cages except the ceiling and the bottom that were of polyvinyl

chloride. Next to the lateral walls and outside the cages, $60 \mathrm{~W}$ incandescent light bulbs were placed to facilitate thermoregulation of the insects. The cages were placed into a climatic room $\left(27 \pm 2{ }^{\circ} \mathrm{C}, 50 \pm 10 \% \mathrm{RH}\right)$ under 12:12 L:D photoperiod. Nymphs and adults were fed once a day with fresh alfalfa (Medicago sativa) and common reed (Phragmites australis). Before last molt, insects were sorted by sex to get virgin adults and after last molt, adults were separated to control the age. When required, insects were sent to the Institute of Advanced Chemistry of Catalonia (CSIC) where they were maintained in similar cages in a climatic room at $29 \pm 3{ }^{\circ} \mathrm{C}, 50 \pm 10 \% \mathrm{RH}$ and 14:10 L:D photoperiod for electroantennographic (EAG) recordings and behavioral activity.

EAG activity. The electroantennogram apparatus was commercially available from Syntech (Kirchzarten, Germany) and the methodology used was based on standardized protocols. ${ }^{20}$ Briefly, one antenna from a non-anesthetized insect was excised, and mounted on an electrode holder (Syntech). A flow of humidified pure air (ca. $750 \mathrm{~mL} / \mathrm{min}$ ) was continuously directed over the antenna to clean the environment and prevent its desiccation. Test stimulations were carried out by giving puffs of air (ca. $200 \mathrm{~mL} / \mathrm{min}$ ) for $200 \mathrm{~ms}$ through 
271

272

273

274

a piece of Whatman filter paper $(2.5 \mathrm{~cm}$ diameter) containing either the solvent $(n$-hexane, 10 $\mu \mathrm{L}$ ) alone as control or the corresponding amount of the chemical, dissolved in hexane, which was allowed to evaporate before the tests. For each compound, two consecutive stimulations of each testing dose were applied at $60 \mathrm{~s}$ intervals over the antennae. Control puffs were applied before and after each pair of stimuli. The output signals were amplified $(10 \times)$, filtered (DC to $1 \mathrm{kHz}$ ) with an IDAC-2 interface (Syntech), further amplified (10×), digitized on a PC and analyzed with the EAG 2000 program (Syntech). The whole EAG preparation was enclosed in a Faraday cage $(70 \times 65 \times 60 \mathrm{~cm})$ connected to the ground to prevent extraneous electric signals. The net EAG responses were calculated by subtracting the mean response to control (hexane) before and after each stimulus from the mean response to the corresponding chemical. Two EAG tests were conducted. In the first assay, a doseresponse profile with $(R, R)$-phytal and the racemic mixture was obtained for males $(\mathrm{N}=4-10$ antennae) and females ( $\mathrm{N}=8-14$ antennae) (8-10 weeks-old) using three doses $(2,20$ and 200 $\mu \mathrm{g})$ for each chemical. In the second assay, the electrophysiological activity elicited by 200 $\mu \mathrm{g}$ of the four diastereomers and the racemic mixture was evaluated. This high dose was required according to the only significant response shown by the antennae in the first assay. Each antenna was stimulated with all compounds in a random sequence and a total of 9-11 male antennae and 8-10 female antennae (7-8 weeks-old) were tested. Prior to each assay, adults were individually isolated for $24 \mathrm{~h}$ to avoid possible interference of odors from conspecific individuals.

Behavioral activity. Behavioral responses of virgin adults of controlled age (7-15 days-old females and 9-16 days-old males to all diastereoisomers of (E)-phytal and ca 5-7 weeks to racemic phytal at $200 \mu \mathrm{g}$ dose were evaluated in a Y-shaped dual-choice olfactometer. The olfactometer consisted of a main glass tube $(21 \mathrm{~cm}$ long x $29 \mathrm{~mm}$ i.d.) with two $10 \mathrm{~cm}$ arms separated by $90^{\circ}$. Each arm was connected to a glass adaptor ( $10.4 \mathrm{~cm}$ long $\mathrm{x} 21 \mathrm{~mm}$ i.d.) 
containing a Whatman filter paper (25 mm diameter) with the test sample or as control.

297 Charcoal-filtered air $(700-800 \mathrm{~mL} / \mathrm{min}$ was passed through the arms to carry the stimuli to the test insects. The system was lit by a $60 \mathrm{~W}$ white bulb centered in the middle of the olfactometer to ensure homogeneous illumination. The experiments were performed from 10:00 a.m. to 6:00 p.m. at $26-29^{\circ} \mathrm{C}$ and $35-50 \%$ RH. The locusts were removed from their containers and kept individually in BugDorm round-bottomed polypropylene containers (Entomopraxis, Barcelona, Spain) covered with mesh screen lid for $24 \mathrm{~h}$ at $26 \pm 2{ }^{\circ} \mathrm{C}, 50 \pm 10 \%$ RH and 14:10 L:D photoperiod. For the experiments, locusts were placed at the base of the main arm, and individuals walking upwind and reaching the middle of one side arm without returning to the intersection point within 5 min were recorded as positive response, and those that failed to choose either arm in the same period were excluded from analysis. A total of 25 insects per diastereomer were tested and assays for each treatment were performed on at least two different days. When half of the insects of an specific experiment was tested, the olfactometer arms were reversed to avoid any possible positional bias. After testing one compound, the Y-tube was cleaned with soap, ethanol, and acetone, allowed to dry and heated in an oven at $200{ }^{\circ} \mathrm{C}$ for $1 \mathrm{~h}$. Then, $10 \mu \mathrm{L}$ of a $20 \mu \mathrm{g} / \mu \mathrm{L}$ solution of the diastereomer in nanograde hexane was deployed in the filter paper, the hexane allowed to evaporate and the paper placed in the treatment container. The number of insects directed to either arm was counted and the treatment response was calculated as the number of insects attracted to the compound relative to the total number of insects moving to either arm of the olfactometer (treatment+control).

Statistical analysis. Mean net electroantennographic responses were subjected to one-way ANOVA followed by Fisher's least significant difference (LSD) post-hoc test. If necessary, data were log-transformed to fulfill the assumptions of normality and heteroscedasticity. For behavioral assays and to assess the null hypothesis that the locust adults had no preference for 
the treatment and control arms the Chi-square goodness-of-fit test was used. In both types of assays, the significance level was set at $\alpha=0.05$ and all tests were performed using SPSS Statistics 17.0.

\section{RESULTS AND DISCUSSION}

\section{Synthesis of all diastereomers of $(E)$-phytal}

It has been reported that phytal, also known as phytenal, is a degradation product of phytol,

widely present in plants. $^{21}$ Therefore, the easiest way to prepare $(7 R, 11 R)$-phytal, $\mathbf{5}$ is by direct oxidation of the corresponding chiral phytol. ${ }^{13,16}$ This diterpenic alcohol had been previously obtained by ring-opening reaction of $(R)$ - $\beta$-methyl- $\beta$-propiolactone with $(R)-4,8$ dimethylnonyl bromide, ${ }^{22}$ and by Mukaiyama reaction of $(3 R, 7 R)-3,7,11$-trimethyldodecanal with silyl enol ether $\mathbf{2 0} .{ }^{19}$ For the oxidation to phytal, active $\mathrm{MnO}_{2}$ in $\mathrm{CH}_{2} \mathrm{Cl}_{2}$ is the reagent of choice since other oxidizing agents, such as Jones reagent/acetone and pyridinium dichromate $/ \mathrm{CH}_{2} \mathrm{Cl}_{2}$ produce variable amounts (4-10\%) of hexahydrofarnesyl acetone, resulting from the double bond oxidative cleavage. ${ }^{13}$ Pyridinium chlorochromate $/ \mathrm{CH}_{2} \mathrm{Cl}_{2}$ has also been successfully used as oxidizing agent apparently with no side reaction. ${ }^{17}$ Racemic (E,Z)-phytal has also been obtained as $E: Z$ 1.2:1 mixture from the corresponding nitrile precursor by reduction with diisobutylaluminium hydride in $\mathrm{CH}_{2} \mathrm{Cl}_{2} \cdot{ }^{18}$ However, no synthetic approaches for the synthesis of the other diastereomers $7 R, 11 S, 7 S, 11 R$, and $7 S, 11 S$ of $(E)$ phytal or the corresponding phytol precursors have been reported.

Synthesis of the diastereomers $(2 E, 7 S, 11 R)$-phytal, 2; $(2 E, 7 R, 11 S)$-phytal, 3; and $(2 E, 7 S, 11 S)$-phytal, 4 was accomplished through the corresponding building blocks $(2 S, 6 R)$ -

6, $(2 R, 6 S)-6$ and $(2 S, 6 S)-6^{18,23}$ from $(R)$ - or $(S)$-citronellal, 7, and methyl $(R)$ - and $(S)-3$ hydroxy-2-methylpropionate, 11, as chiral sources (Figures 3 and 4). Key processes of our synthesis involve: i) $\mathrm{Li}_{2} \mathrm{CuCl}_{4}$-mediated coupling of the differently protected alcohol groups 

of chiral 2-methyl-1,3-propanediol, one of them as tetrahydropyranyl (THP) or tertbutyldimethylsilyl (TBDMS) ether and the other as a suitable leaving group such as tosylate or mesylate, ${ }^{24}$ and ii) Lewis-acid catalyzed Mukaiyama aldol reaction ${ }^{25}$ between silyl enol ether 20 with a suitable chiral aldehyde such as $(3 S, 7 R)-\mathbf{1 8}$, to introduce a 5-carbon prenyl unit. ${ }^{19}$ Reduction of $(R)$-citronellal, 7 to $(R)$-citronellol, 8 followed by hydrogenation $\left(\mathrm{H}_{2}\right.$, $10 \% \mathrm{Pt} / \mathrm{C}, \mathrm{EtOH})$ provided alcohol $(R)-9$ in $92 \%$ overall yield, which was transformed into the corresponding bromide $(R)$-10 (N-bromosuccinimide, $\mathrm{Ph}_{3} \mathrm{P}, \quad \mathrm{CH}_{2} \mathrm{Cl}_{2}, \quad 90 \%$ ) Tetrahydropyranyl-protected tosylate $(R)-\mathbf{1 4}$ was prepared by protection of hydroxyester $(R)$ $\mathbf{1 1}$ as tetrahydropyranyl ether $(R)-\mathbf{1 2}^{26-28}$ followed by diisobutylaluminium hydride reduction in toluene/THF at $-20^{\circ} \mathrm{C}$, to produce mono-protected diol $(S)-\mathbf{1 3}$ in $81 \%$ overall yield from $(R)$-11. It should be noted that the intermediate aldehyde can be isolated in good yield when the reaction is performed in $\mathrm{CH}_{2} \mathrm{Cl}_{2}$ at $-78{ }^{\circ} \mathrm{C} .{ }^{28}$ Tosylation of $(S)-\mathbf{1 3}$ under standard conditions provided the required tosylate $(R)-\mathbf{1 4}$ in $87 \%$ yield. Coupling reaction of $(R)-\mathbf{1 4}$ with the Grignard reagent derived from $(R)-\mathbf{1 0}$ under Schlosser's conditions ${ }^{29}$ followed by acid hydrolysis afforded the intermediate $(2 S, 6 R)-6$ in $66 \%$ overall yield from $(R)-14$ (Figure 3). The alternative protection of alcohol $(R)-\mathbf{1 1}$ as tert-butyldimethylsilyl ether afforded mixtures of products when the corresponding tosylate or mesylate was reacted with bromide $(R)-10$ (not shown). Mesylation of $(2 S, 6 R)-6$ followed by cyanation provided nitrile $(3 S, 7 R)$ $\mathbf{1 7}$ that was reduced with diisobutylaluminium hydride in hexane to aldehyde $(3 S, 7 R)-\mathbf{1 8}$ in $72.6 \%$ overall yield from $(2 S, 6 R)-6$ (Figure 4$)$. Introduction of a new prenyl unit into the chain of aldehyde $\mathbf{1 8}$ was achieved through Mukaiyama aldol reaction with silyl dienol ether 20. ${ }^{19}$ The protected enol ether ${ }^{30}$ was obtained by deprotonation of ester 19 followed by silylation in $45.4 \%$ yield from dimethylacrylic acid. Coupling reaction of aldehyde $(3 S, 7 R)$ 18 with vinyl ether $\mathbf{2 0}$ in $\mathrm{TiCl}_{4} / \mathrm{CH}_{2} \mathrm{Cl}_{2}$ afforded mixture of stereomeric alcohols 21 at C-5, from which isomer $(2 E, 5 R S, 7 S, 11 R)-\mathbf{2 1}$ was obtained after careful column chromatography 
purification. None of the $Z$ isomer was isolated (Figure 4). The Mukaiyama reaction was used by Fleming et al. ${ }^{19}$ to transform aldehyde $(3 R, 7 R)-18$ into $(7 R, 11 R)$-phytol as a $3: 1 E: Z$ mixture after mesylation and lithium aluminium hydride reduction. In our hands, however, direct treatment of mesylate $(2 E, 5 R S, 7 S, 11 R)-22$ with lithium aluminium hydride under different conditions gave an impractical mixture of products. Therefore, after an extensive optimization of the reduction conditions, we found that this process is preferably implemented in two steps: a first chemoselective reduction of the conjugated ester group of 22 with diisobutylaluminium hydride in toluene at $-78^{\circ} \mathrm{C}$ to provide hydroxy mesylate (2E,5RS,7S,11R)-23 in almost quantitative yield, followed by lithium aluminium hydride/ether treatment at room temperature. However, the second elimination reaction was not completely chemoselective since a small proportion $(5 \%)$ of the $\alpha, \beta, \gamma, \delta$ diunsaturated alcohol $(2 E, 4 E, 7 S, 11 R)-\mathbf{2 4 a}$ was also obtained from the competing dehydromesylation reaction. In addition, $(7 S, 11 R)-2,3$-dihydrophytol (17\%) was also obtained from overreduction. The expected $(2 E, 7 S, 11 R)$-phytol, 24 was obtained in $46.6 \%$ overall yield from alcohol 21. Selective oxidation of $\mathbf{2 4}$ with active $\mathrm{MnO}_{2}$ in dichloromethane as previously described, ${ }^{29}$ gave, after careful column chromatography purification, a first batch of $(2 E, 7 S, 11 R)$-phytal, 2, 94\% pure as $96: 4 E: Z$ mixture, containing $6 \%$ of the $\alpha, \beta, \gamma, \delta$ diunsaturated aldehyde $[(2 E, 4 E, 7 S, 11 R)-\mathbf{2 a}$. Two more fractions from the column provided the expected phytal 2 less pure (76-86\%). The calculated yield of pure phytal was 58\% (Figure 4). Since $\mathrm{MnO}_{2}$ is a well-known selective oxidation reagent for allylic alcohols, ${ }^{31}$ the 2,3-dihydrophytol present in the alcohol mixture was not oxidized under the conditions used and was easily removed by column chromatography. It should be noted that the $E$ isomer of all synthetic diastereomers partially isomerized to the $Z$ isomer in few hours at room temperature to reach a ca. 75:25 E:Z stereochemical mixture. Therefore, all the diastereomers 
were stabilized with $20 \% \mathrm{w} / \mathrm{w}$ of BHT for the electroantennographic and behavioral assays. In previous tests no activity was elicited by the antioxidant.

\section{Electroantennographic activity}

In the first experiment aimed to determine the electrophysiological activity elicited by different doses of $(2 E, 7 R, 11 R)$-phytal, 5 relative to the racemic material, female antennae were more sensitive than male antennae, particularly at the highest doses tested (20 and 200 $\mu g$ ) (Figure 5). Within each sex, the depolarization responses were always higher to stimulations with $(R, R)$-phytal, except for the $2 \mu \mathrm{g}$ dose on female antennae, although significant difference $(\mathrm{P} \leq 0.05)$ was only apparent at the intermediate dose $(20 \mu \mathrm{g})$. In the second experiment, aimed to assess the electroantennographic responses of each synthetic diastereomer relative to the racemic material, female antennae responded also better to all diastereomers than male antennae, with the depolarizations induced by the $R, R$ diastereomer on females being significantly higher than those displayed by any other diastereomer (Figure 6). In males, the same trend was noticed with the highest statistically significant activity being displayed by the $R, R$ diastereomer. In this regard, it should be noticed the $R, R$ configuration of natural phytol, a very common component of locust food, so it is reasonable to argue that this configuration is maintained also in its degradation products phytal ${ }^{13}$ and phytanic acid ${ }^{15}$. In both sexes the following more active diastereomers were $R, S(42 \%$ and $58 \%$ relative to $R, R$ in males and females, respectively) and $S, R(53 \%$ and $56 \%$, respectively), while the $S, S$ and the racemic mixture elicited the weakest response. In no case, the difference was significant.

In all cases, the net electroantennographic depolarizations elicited by the different diastereomers were quite small, probably because of the very low volatility of the pheromone, in spite of the huge amount of the compound tested, and particularly by the small number of chemoreceptor organs in the antenna. ${ }^{32,33}$ In this regard, the antennal sensory 
system of acridids present a phenotypic variation in the number and type of sensilla arising from differences in food habits, crowding and previous odor environmental experience. ${ }^{34}$ In the Moroccan locust, like in other Acrididae, ${ }^{35}$ the most abundant sensilla are basiconic

422 followed by coleoconic, trichoid and chaotic. ${ }^{36}$ Although knowledge of the molecular 423 mechanisms of olfaction in locusts is highly unknown, it appears established that odorant receptors expressed in neurons located in sensilla coeloconica would be tuned to plant and fruit odors, ${ }^{37}$ those expressed in basiconic sensilla would be tuned to odors related to social behaviors, ${ }^{38}$ and receptors expressed in neurons of sensilla trichodea are probably related to sexual recognition. ${ }^{39}$ As result of the low depolarizations elicited along with the low stability of the signal, only a limited number of antennae were considered for analysis (e.g. in experiment 1 from 19-20 male and female antennae only 4-10 for males and 8-14 for females, respectively, were used). A similar situation had been found with phytol, which gave small, if any, electroantennogram responses although this terpenic alcohol was found to be tuned to a specific receptor cell in Spodoptera littoralis eliciting a clear response. ${ }^{40}$

\section{Behavioral activity}

In previous experiments, sexually mature 7-15 days-old virgin males and females did not elicit a significant preferential response towards the $(R, R)$-phytal at the dose of $20 \mu \mathrm{g}$ (data not shown). When sexually mature 7-15 days-old virgin females were tested, the $(R, R)$-phytal at the dose of $200 \mu \mathrm{g}$ was clearly the most effective diastereomer in a dual-choice $\mathrm{Y}$ olfactometer with 15 insects (79\% response) being attracted to the chemical-containing arm and 4 individuals (21\% response) to the control arm (6 locusts did not respond) (Table 1). The response to the treatment was significant ( $\mathrm{p}=0.012$, Chi-square goodness-of-fit test). Similarly, the $(R, S)$ - and $(S, S)$-phytal attracted more insects to the arm containing the chemical than the control arm but the difference was not significant $(p=0.275$ and 0.180 , respectively). The $(S, R)$-phytal and the racemic material did not induce any preferential 
response on the insects tested although the latter was assayed on field-collected insects of 5-7 weeks-old (Table 1). When all diastereomers were tested on males of similar age, neither one elicited a significant preferential response towards the treatment arm (Table 1). As for

447 females, $(R, R)$ - and $(S, S)$-phytal were more attractive than the other two diastereomers but the 448 difference $v s$ control was not significant. The racemic material was also ineffective.

449 Previous experiments conducted with racemic phytal $(20 \mu \mathrm{g})$ on a bioassay arena ${ }^{41}$ with 450 groups of 10-15 adults resulted in a preferred attraction to females over males, but attraction to males was also significant. ${ }^{13}$ In this regard, we postulated that the attraction to males could

452 be the result of a male-produced sex pheromone that is eavesdropped on by male congeners to locate possible mating partners. ${ }^{42}$ Some points can be considered to explain the apparently contradictory results obtained in both types of assay. First, the different design of the bioassays; second, the age of insects (7-16 days old in the Y olfactometer and 10-30 days old in the arena bioassay); and third, the different state of the insects used, i.e. groups of 10-15 individuals in the arena experiment $v s$ single locusts in the $\mathrm{Y}$ olfactometer. It may be possible that grouped individuals produce other minor components in addition to phytal to attract 459 other males whereas single insects do not. This speculation will be tackled in future 460 investigations of our group.

In summary, we have synthesized and tested electrophysiologically and behaviorally all diastereomers of $(E)$-phytal, and assessed that the $R, R$ isomer is the most active, confirming

463 the initial chromatographic identification as component of the sex pheromone of the 464 Moroccan locust.

\section{ASSOCIATED CONTENT}

\section{Supporting Information}


467 Synthesis of intermediate $(2 S, 6 R)-6$, and stereoisomers $(2 E, 7 R, 11 S)$-phytal, 3; $(2 E, 7 S, 11 S)$ -

468 phytal, 4 and $(2 E, 7 R, 11 R)$-phytal 5. ${ }^{1} \mathrm{H}$ and ${ }^{13} \mathrm{C}$ NMR spectra of all stereoisomers. This 469 material is available free of charge via the Internet at http://pubs.acs.org.

\section{AUTHOR INFORMATION}

\section{Corresponding Authors}

472 *Phone: +34 93 4006120; Fax +34 93 2045904; E-mail: agpqob@cid.csic.es.

473 E-mail: cqlqob@cid.csic.es

474 ORCID

475 Angel Guerrero: 0000-0003-2323-2691

476 Sergio López: 0000-0002-8641-1622

477 José María Álvarez-Calero: 0000-0002-4506-0299

478 Carmen Quero: 0000-0003-3599-2778

$479 \quad$ Funding

480 We gratefully acknowledge MINECO for an FPI contract to A.D., a postdoctoral contract to 481 V.E.R. and J.M.A. and financial support (AGL2012-39869-C02-01, AGL2015-66469-R) 482 with assistance from the European Regional Development Fund. E. Beltran (Regional 483 Community of Aragón) provided financial support for fieldwork.

\section{Notes}

485 The authors declare no competing financial interest.

\section{ACKNOWLEDGEMENTS}

487 We gratefully acknowledge J. Coll for helpful discussions, E. Faggi for help in some EAG experiments, G. Rosell for HRMS measurements, S. Cahill and M. Casals for help in the bioassays. C. Muñoz and T. Ruiz provided field collected insects and I. Tenas and P. Esteban assisted in the fieldwork. 


\section{REFERENCES}

492 (1) Steedman, A. The locust handbook. Overseas Development National Resources Institute: London, $493 \quad 1988$

494 (2) Showler, A. T. A summary of control strategies for the desert locust, Schistocerca gregaria 495 (Forskål). Agr. Ecosyst. Environ. 2002, 90, 97-103.

496 (3) Cressman, K. Monitoring desert locusts in the Middle East: An overview. Yale F. ES. Bull. 1998, $497 \quad 103,123-141$.

498

(4) Enserink, M. Can the war on locusts be won? Science (Washington DC) 2004, 306, 1880-1882.

(5) Arthurs, S.; Thomas, M. B.; Langewald, J. Field observations of the effects of fenitrothion and Metarhizium anisopliae var. acridum on non-target ground dwelling arthropods in the Sahel. Biol. Control 2003, 26, 333-340.

502

(6) El Ghadraoui, L.; Petit, D.; Picaud, F.; El Yamani, J. Relationship between labrum sensilla number in the Moroccan locust Dociostaurus maroccanus and the nature of its diet. J. Orthop. Res. 2002, 11, $11-18$.

505

(7) Latchininsky, A. V.; Launois-Luong, M. H. Le criquet marocain, Dociostaurus maroccanus (Thunberg, 1815), dans la partie orientale de son aire de distribution : étude monographique relative à l'ex-URSS et aux pays proches. CIRAD-PRIFAS: Montpellier/France, VIZR, St Petersburg, Russia, 1992

509

(8) Uvarov, B. P. Grasshoppers and Locusts. A Handbook of General Acridology. Vol. II: Behaviour,

510 Ecology, Biogeography Population Dynamics. Centre for Overseas Pest Research.: London, 1977 pp $511 \quad 613$

512 (9) Anonymous Locust and Grasshopper Agricultural Manual. Center for Overseas Pest Research:

513 London, 1982

514 (10) Simpson, S. J.; Sword, G. A. Locusts. Curr. Biol. 2008, 18, 364-366.

515 (11) Latchininsky, A. V. Moroccan locust Dociostaurus maroccanus (Thunberg, 1815): a faunistic 516 rarity or an important economic pest? J. Insect Conserv. 1998, 2, 167-178. 
517 (12) CPAGE Reuniones anuales de los grupos de trabajo fitosanitarios. Ministerio de Agricultura, 518 Pesca y Alimentación: Madrid, 2004-2007 ISBN: 2004, 84-491-0674-5; 2005, 84-491-0735-0; 2006, 978-84-491-0785-6; 2007, 978-84-491-0853-2.

(13) Fürstenau, B.; Muñoz, L.; Coca-Abia, M.; Rosell, G.; Guerrero, A.; Quero, C. Phytal: A candidate sex pheromone component of the Moroccan locust Dociostaurus maroccanus. ChemBioChem 2013, 14, 1450-1459. Corrigendum: ChemBioChem 2013, 1414, 1391-1397. (14) Rontani, J.-F.; Bonin, P. C.; Volkman, J. K. Biodegradation of free phytol by bacterial communities isolated from marine sediments under aerobic and denitrifying conditions. Appl. Environ. Microbiol. 1999, 65, 5484-5492.

(15) van den Brink, D. M.; Wanders, R. J. A. Phytanic acid: production from phytol, its breakdown and role in human disease. Cell. Mol. Life Sci. 2006, 63, 1752. (16) Jackman, L. M.; Rüegg, R.; Ryser, G.; von Planta, C.; Gloor, U.; Mayer, H.; Kofler, M.; Isler, O.; Schudel, P. Über die Chemie des Vitamins K. 2. Mitteilung. Totalsynthese und Stereochemie von trans- und cis-( $\left.7^{\prime} \mathrm{R}, 11^{\prime} \mathrm{R}\right)-$ Phyllochinon und verwandten Verbindungen. Helv. Chim. Acta 1965, 48, 1332-1349.

(17) Saikia, D.; Parihar, S.; Chanda, D.; Ojha, S.; Kumar, J. K.; Chanotiya, C. S.; Shanker, K.; Negi,

A. S. Antitubercular potential of some semisynthetic analogues of phytol. Bioorg. Med. Chem. Lett. 2010, 20, 508-512.

(18) Gembus, V.; Sala-Jung, N.; Uguen, D. Efficient access to (all-rac)-alpha-tocopherol acetate by a Crombie chromene synthesis. Bull. Chem. Soc. Jpn. 2009, 82, 843-854.

(19) Fleming, I.; Maiti, P.; Ramarao, C. Stereocontrol of 1,5-related stereocentres using an intermediate silyl group-the diastereoselectivity of nucleophilic attack on a double bond adjacent to a stereogenic centre carrying a silyl group. Org. Biomol. Chem. 2003, 1, 3989-4004. beet armyworm Spodoptera exigua. J. Chem. Ecol. 2010, 36, 778-786. active (R,R)-phytol. Tetrahedron Lett. 1981, 22, 4823-4826. 
545 (23) Huo, S.; Negishi, E.-i. A convenient and asymmetric protocol for the synthesis of natural

546 products containing chiral alkyl chains via Zr-catalyzed asymmetric carboalumination of alkenes.

547 Synthesis of phytol and vitamins E and K. Org. Lett. 2001, 3, 3253-3256.

548 (24) Schmid, R.; Antoulas, S.; Rüttimann, A.; Schmid, M.; Vecchi, M.; Weiserb, H. Synthesis of all

549 four stereoisomers of (E)-vitamin KT (phylloquinone), analysis of their diastereoisomeric and

550 enantiomeric purities and determination of their biopotencies. Helv. Chim. Acta 1990, 73, 1276-1299.

551 (25) Ishida, A.; Mukaiyama, T. Total synthesis of ( \pm )-variotin and its analogs. Bull. Chem. Soc. Jpn. $552 \quad \mathbf{1 9 7 8}, 51,2077-2081$.

553 (26) Mori, K. Synthesis of all the stereoisomers of 6-methyl-2-octadecanone, 6,14-dimethyl-2-

554 octadecanone and 14-methyl-2-octadecanone, the components of the female-produced sex pheromone 555 of a moth, Lyclene dharma dharma. Tetrahedron 2009, 65, 2798-2805.

556 (27) Nakamura, Y.; Mori, K. Synthesis of (3S,7S)- and (3S,7S,15S)-stereoisomers of 3,7-dimethyl-2557 heptacosanone and 3,7,15-trimethyl-2-heptacosanone, the ketones identified from the locust

558 Schistocerca gregaria. Eur. J. Org. Chem. 2000, 2000, 1307-1312.

559 (28) Spaltenstein, A.; Carpino, P. A.; Miyake, F.; Hopkins, P. B. New approaches to the synthesis of 560 trans-alkene isosteres of dipeptides. J. Org. Chem. 1987, 52, 3759-3766.

561 (29) Fouquet, G.; Schlosser, M. Improved carbon-carbon linking by controlled copper catalysis. 562 Angew. Chem. Int. Ed. Eng. 1974, 13, 82-83.

563 (30) Fleming, I.; Goldhill, J.; Paterson, I. $\gamma$-Alkylation of unsaturated ketones and esters: zinc bromide-catalysed alkylation of $O$-silylated dienolates. Tetrahedron Lett. 1979, 20, 3209-3212.

565 (31) Fieser, F.; Fieser, M., Reagents for Organic Synthesis. John Wiley \& Sons, Inc.: New York, 566 1967; 637-643; 1012-1013.

567 (32) Chen, H. H.; Zhao, Y. X.; Kang, L. Antennal sensilla of grasshoppers (Orthoptera: Acrididae) in 568 relation to food preferences and habits. J. Biosci. (Bangalore) 2003, 28, 743-752.

569 (33) Dumas, P.; Tetreau, G.; Petit, D. Why certain male grasshoppers have clubbed antennae? C. R. 570 Biol. 2010, 333, 429-437. 
571 (34) Guerrero, A.; Coca-Abia, M.; Quero, C. The Moroccan locust Dociostaurus maroccanus

572 (Thunberg): Biology, economic impact and control. In Advances in Animal Science and Zoology;

573 Jenkins, O. P., Ed. Nova Science Pub., Inc.: New York, 2017; Vol. 10, p 260.

574 (35) Ochieng, S. A.; Hallberg, E.; Hansson, B. Fine structure and distribution of antennal sensilla of 575 the desert locust, Schistocerca gregaria (Orthoptera: Acrididae). Cell Tissue Res. 1998, 291, 252-536.

576 (36) Fürstenau, B. Comunicación química intraespecífica de Coroebus spp. (Coleoptera: Buprestidae)

577 y Dociostaurus maroccanus /Orthoptera: Acrididae), dos insectos plaga de la Península Ibérica. Ph.D.

578 Dissertation, University of Barcelona, Barcelona, 2011.

579 (37) Anton, S.; Hansson, B. S. Antennal lobe interneurons in the desert locust Schistocerca gregaria 580 (Forskal): Processing of aggregation pheromones in adult males and females. J. Comp. Neurol. 1996, $581370,85-96$.

582 (38) Hansson, B. S.; Ochieng, S. A.; Grosmaitre, X.; Anton, S.; Njagi, P. G. N. Physiological responses and central nervous projections of antennal olfactory receptor neurons in the adult desert locust, Schistocerca gregaria (Orthoptera: Acrididae). J. Comp. Physiol. A 1996, 179, 157-167. (39) Ochieng, S. A.; Hansson, B. S. Responses of olfactory receptor neurones to behaviourally important odours in gregarious and solitarious desert locust, Schistocerca gregaria. Physiol. Entomol. 1999, 24, 28-36. deterring components in larval frass of Spodoptera littoralis (Boisd.) (Lepidoptera: Noctuidae): A behavioural and electrophysiological evaluation. J. Insect Physiol. 1993, 39, 129-137. gregarious desert locust, Schistocerca gregaria (Forskål) (Orthoptera: Acrididae). J. Chem. Ecol. 1996, 22, 2273-2281. 


\section{FIGURE CAPTIONS}

598 Figure 1. Structure of $( \pm)-(Z / E)$-phytal, 1.

599 Figure 2. Structure of all diastereoisomers of $(E)$-phytal, 2-5.

600 Figure 3. Synthesis of intermediate (2S,6R)-6. (Abbreviations: NBS, N-bromosuccinimide;

601 DHP, 3,4-dihydro-2H-pyran; DIBAH, diisobutylaluminium hydride; TsCl, p-toluenesulfonyl 602 chloride; TEA, triethylamine).

603 Figure 4. Synthesis of $(2 E, 7 S, 11 R)$-phytal, 2. (Abbreviations: $\mathrm{MsCl}$, methanesulfonyl 604 chloride; TEA, triethylamine; DIBAH, diisobutylaluminium hydride; LDA, lithium 605 diisopropylamine; TMSCl, chlorotrimethylsilane).

606 Figure 5. Mean electroantennographic responses $(\mathrm{mV} \pm \mathrm{SEM})$ from antennae of $D$. 607 maroccanus males $(\mathrm{N}=4-10)$ and females $(\mathrm{N}=8-14)$ to different doses of $(R, R)$ - and racemic 608 phytal. Means with different letters within sex are statistically different (one-way ANOVA 609 followed by LSD post-hoc test, $\alpha=0.05$ ).

610 Figure 6. Mean electroantennographic responses $(\mathrm{mV} \pm \mathrm{SEM})$ from antennae of $D$. 611 maroccanus males $(\mathrm{n}=9-11)$ and females $(\mathrm{N}=8-10)$ to $200 \mu \mathrm{g}$ of the four diastereoisomers of 612 (E)-phytal and the racemic mixture. Means with different letters within sex are statistically 613 different (one-way ANOVA followed by LSD post-hoc test, $\alpha=0.05$ ). 
Table 1. Behavioral Response of Virgin D. maroccanus Females and Males to all Diastereomers of (E)-Phytal and the Racemic Material in a Dual-Choice Y Olfactometer

\begin{tabular}{|cccccccc|}
\hline Compound & N & Sex & Age (d) & Treatment & Control & $\begin{array}{c}\text { Treatment } \\
\text { response (\%) }\end{array}$ & Significance \\
\hline$(R, R)$-phytal & 25 & F & $7-15$ & 15 & 4 & 78.95 & $*$ \\
\hline$(R, S)$-phytal & 25 & F & $7-15$ & 13 & 8 & 61.90 & NS \\
\hline$(S, S)$-phytal & 25 & F & $7-15$ & 13 & 7 & 65.00 & NS \\
\hline$(S, R)$-phytal & 25 & F & $7-15$ & 10 & 10 & 50.00 & NS \\
\hline$( \pm)$-phytal & 24 & F & -- & 10 & 11 & 47.62 & NS \\
\hline$(R, R)$-phytal & 25 & M & $9-16$ & 13 & 10 & 56.52 & NS \\
\hline$(R, S)$-phytal & 25 & M & $9-16$ & 9 & 9 & 50.00 & NS \\
\hline$(S, S)$-phytal & 25 & M & $9-16$ & 13 & 9 & 59.09 & NS \\
\hline$(S, R)$-phytal & 25 & M & $9-16$ & 8 & 15 & 34.78 & NS \\
\hline$( \pm)$-phytal & 21 & M & --1 & 8 & 10 & 44.44 & NS \\
\hline
\end{tabular}

${ }^{*} \mathrm{p}=0.012($ Chi-square goodness-of-fit test at $\alpha=0.05)$

$\mathrm{NS}=$ non significant

${ }^{1}$ Unknown age (field collected). 


\section{Table of Contents Graphic}

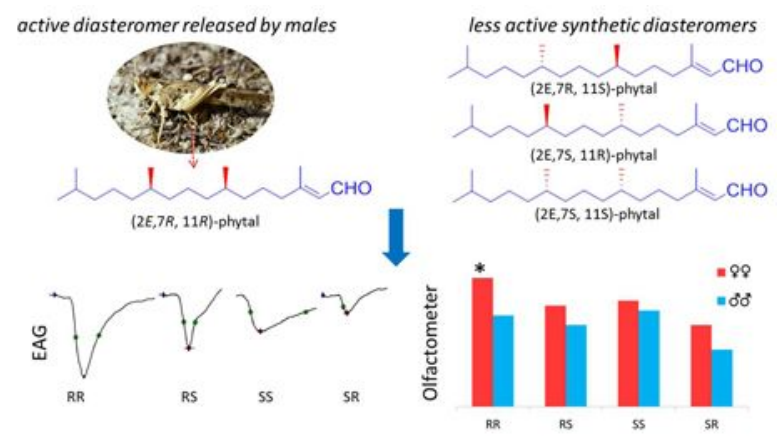




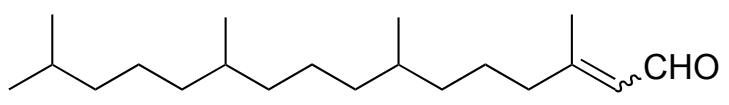

$( \pm)-(Z / E)-$ phytal, 1

Figure 1 


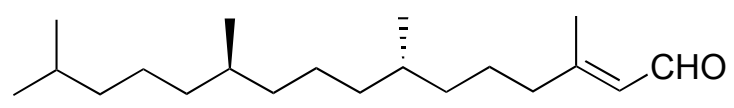

(2E,7S,11R)-phytal, 2

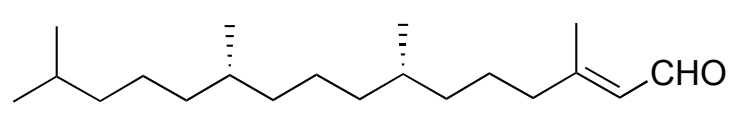

(2E,7S,11S)-phytal, 4

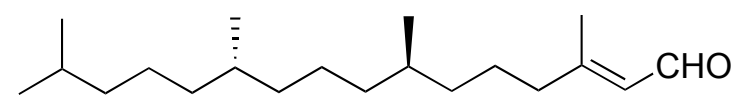

(2E,7R,11S)-phytal, 3

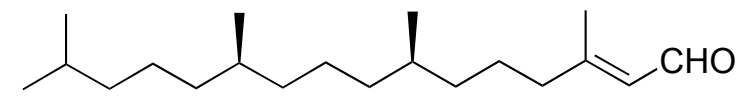

$(2 E, 7 R, 11 R)$-phytal, 5

Figure 2 
<smiles>CC(C)=CCCC(C)CC=O</smiles>

$(R)-7$ $\mathrm{NaBH}_{4}, \mathrm{EtOH}$<smiles>CC(C)=CCCC(C)CCO</smiles>

$(R)-8$

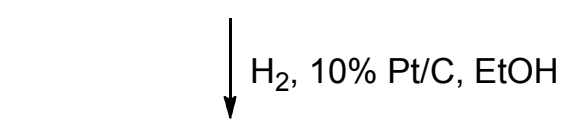<smiles>CC(C)CCCC(C)CCO</smiles>

$(R)-9$<smiles>ClCP[Pb]=[Pb]</smiles><smiles>CC(C)CCCC(C)CCBr</smiles>

$(R)-10$

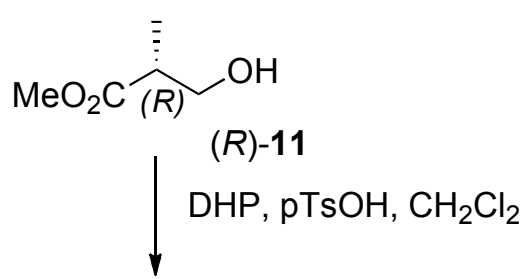<smiles>CC(=O)C[C@H](C)[OH+]P</smiles>

$(R)-12$

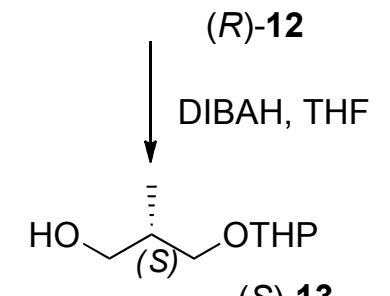

(S)-13

TsCl, TEA, $\mathrm{CH}_{2} \mathrm{Cl}_{2}$

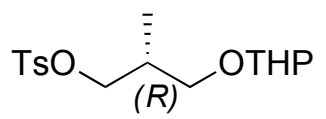

$(R)-14$

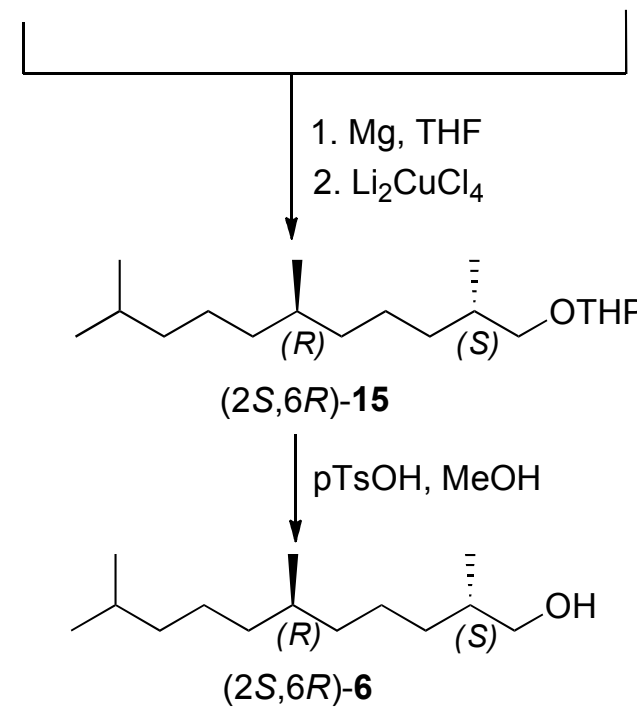

Figure 3 

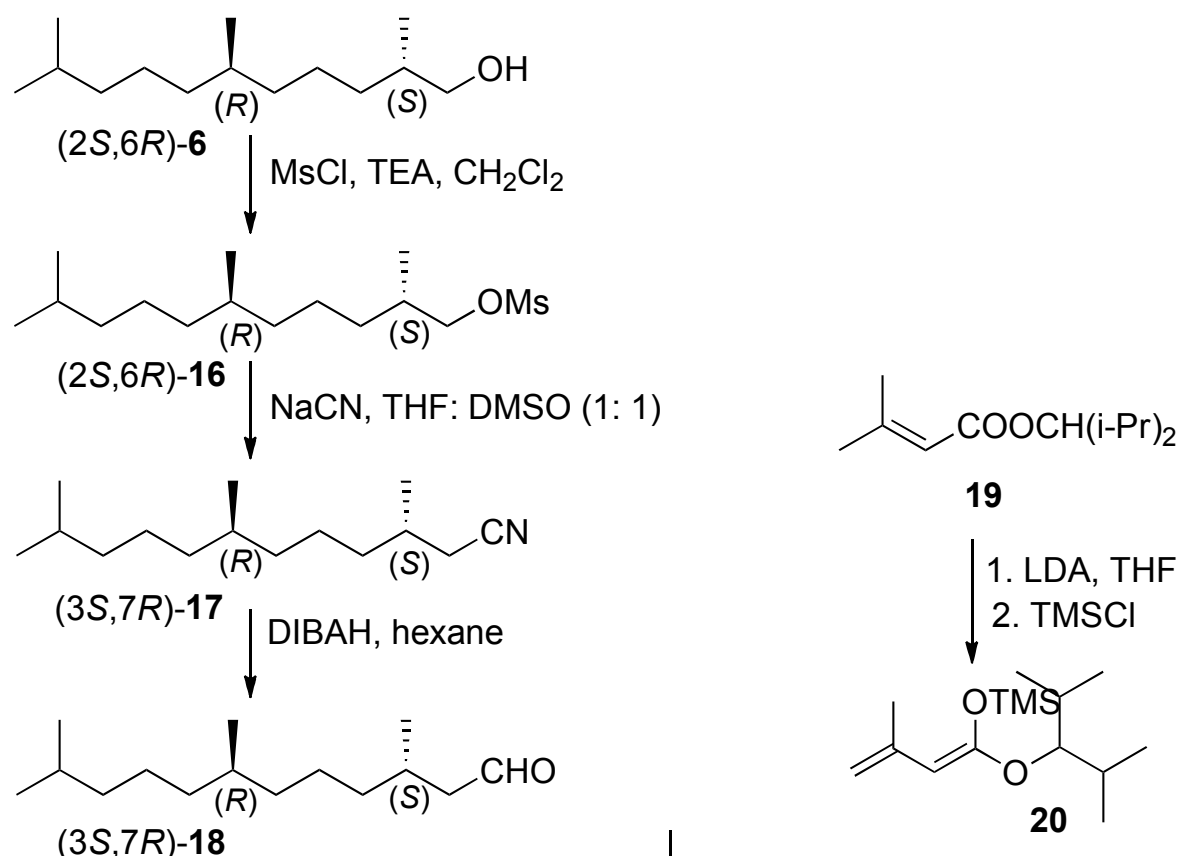

19

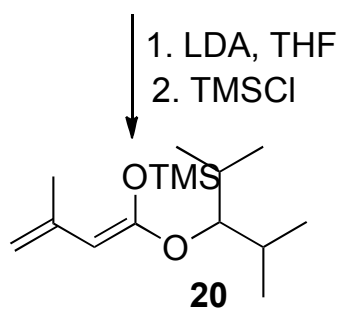

$\mathrm{TiCl}_{4}, \mathrm{CH}_{2} \mathrm{Cl}_{2}$

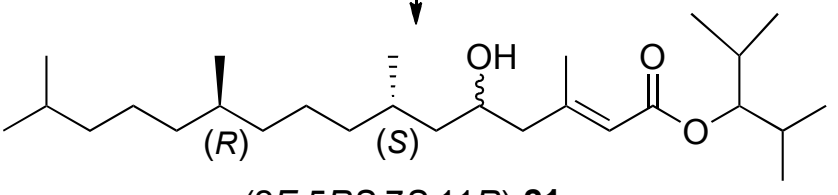

(2E,5RS, 7S, 11R)-21
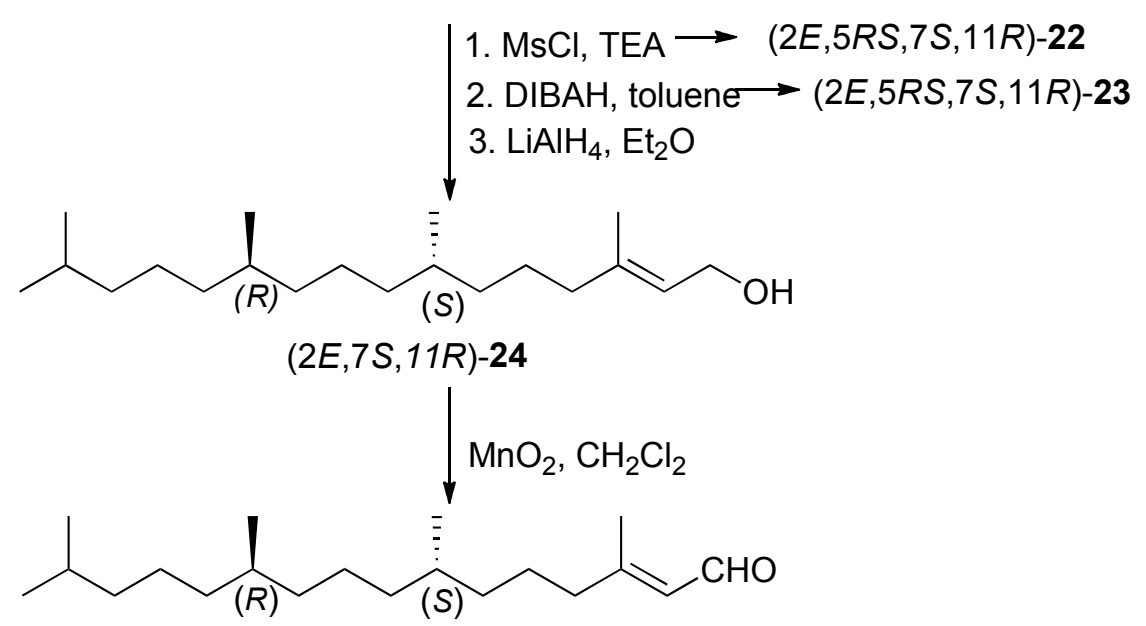

(2E,7S, 11R)-phytal, 2

Figure 4 


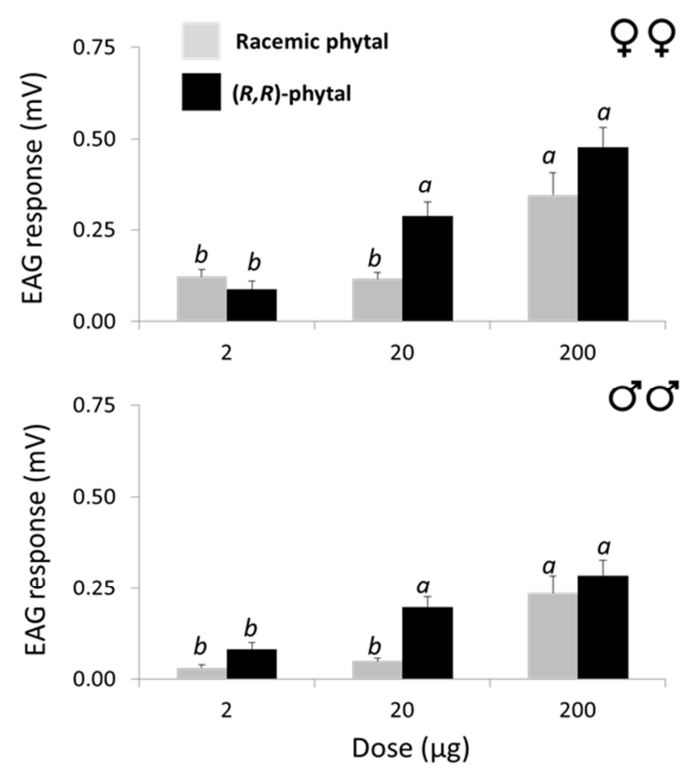

Figure 5 


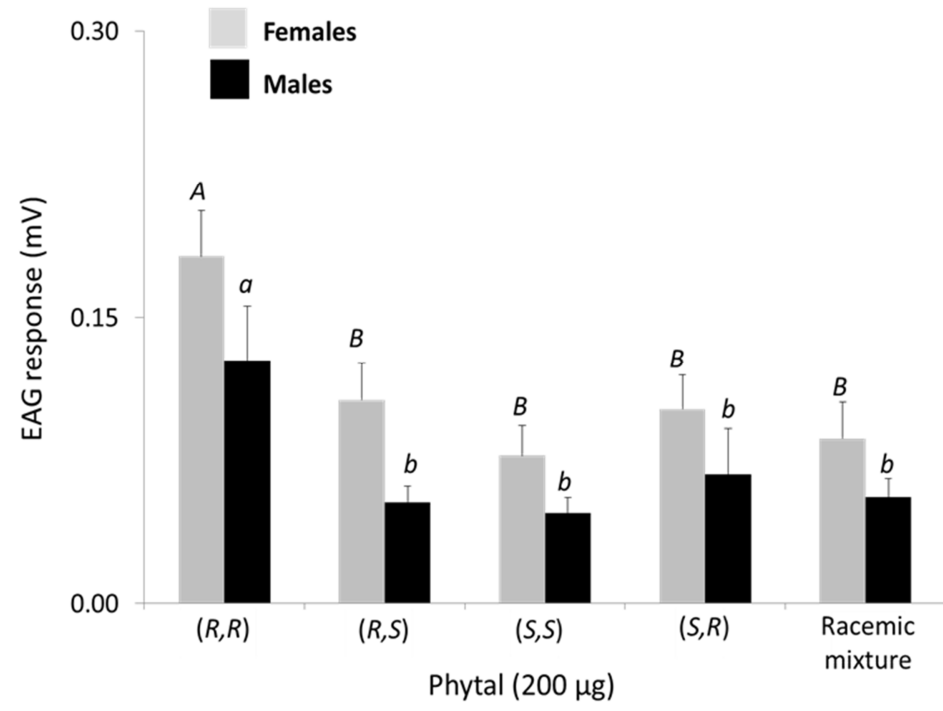

Figure 6 